\title{
GSTA4 wt Allele
}

National Cancer Institute

\section{Source}

National Cancer Institute. GSTA4 wt Allele. NCI Thesaurus. Code C116646.

Human GSTA4 wild-type allele is located in the vicinity of $6 \mathrm{p} 12.1$ and is approximately 17 $\mathrm{kb}$ in length. This allele, which encodes glutathione S-transferase A4 protein, plays a role in the metabolism of endogenous and exogenous small hydrophobic molecules. 